\title{
The Fatty Acid Lipid Metabolism Nexus in COVID-19
}

\author{
Jerome E. Tanner ${ }^{1}$ and Caroline Alfieri ${ }^{1,2, *}$ \\ 1 Laboratory of Viral Pathogenesis, Research Centre, CHU Sainte-Justine, 3175 Côte Sainte-Catherine Road, \\ Montréal, QC H3T 1C5, Canada; jerome.tanner.hsj@ssss.gouv.qc.ca \\ 2 Département de Microbiologie, Infectiologie et Immunologie, Université de Montréal, \\ 2900 Boul. Édouard-Montpetit, Montréal, QC H3T 1J4, Canada \\ * Correspondence: carolina.alfieri@umontreal.ca; Tel.: +1-514-345-4931 (ext. 6135)
}

check for updates

Citation: Tanner, J.E.; Alfieri, C. The Fatty Acid Lipid Metabolism Nexus in COVID-19. Viruses 2021, 13, 90. https://doi.org/10.3390/v13010090

Academic Editors: Sara N. Richter and Louis Flamand

Received: 18 November 2020

Accepted: 7 January 2021

Published: 11 January 2021

Publisher's Note: MDPI stays neutral with regard to jurisdictional clai$\mathrm{ms}$ in published maps and institutional affiliations.

Copyright: (C) 2021 by the authors. Licensee MDPI, Basel, Switzerland. This article is an open access article distributed under the terms and conditions of the Creative Commons Attribution (CC BY) license (https:// creativecommons.org/licenses/by/ $4.0 /)$.

\begin{abstract}
Enteric symptomology seen in early-stage severe acute respiratory syndrome (SARS)-2003 and COVID-19 is evidence of virus replication occurring in the intestine, liver and pancreas. Aberrant lipid metabolism in morbidly obese individuals adversely affects the COVID-19 immune response and increases disease severity. Such observations are in line with the importance of lipid metabolism in COVID-19, and point to the gut as a site for intervention as well as a therapeutic target in treating the disease. Formation of complex lipid membranes and palmitoylation of coronavirus proteins are essential during viral replication and assembly. Inhibition of fatty acid synthase (FASN) and restoration of lipid catabolism by activation of AMP-activated protein kinase (AMPK) impede replication of coronaviruses closely related to SARS-coronavirus-2 (CoV-2). In vitro findings and clinical data reveal that the FASN inhibitor, orlistat, and the AMPK activator, metformin, may inhibit coronavirus replication and reduce systemic inflammation to restore immune homeostasis. Such observations, along with the known mechanisms of action for these types of drugs, suggest that targeting fatty acid lipid metabolism could directly inhibit virus replication while positively impacting the patient's response to COVID-19.
\end{abstract}

Keywords: endoplasmic reticulum stress response; unfolded protein response; mTORC1; SREBP-1; nonstructural protein; membrane protein; spike protein; envelope protein; replicative organelle; antiviral

\section{Introduction}

All viruses repurpose cell catabolism and anabolism to generate energy and macromolecules for efficient replication; however, the mechanisms and consequences of SARScoronavirus-2 (CoV-2) lipid metabolic reprogramming is largely unexplored. In this review, we examine fatty acid lipid metabolism in the context of COVID-19 at the organismal, cellular and macromolecular levels. With this basis of understanding, we propose two rational treatment options that directly target the virus's lipid dependency as well as strengthen the patient's response to SARS-CoV-2 infection.

\section{Digestive System Involvement in COVID-19}

Mammalian cell proliferation and the formation and maintenance of their larger organ system counterparts require an adequate supply of energy and cellular building blocks including fatty acid phospholipids which represent the major constituent of biological membranes [1]. Changes in membrane phospholipid composition and acyl length determine the biophysical properties of cell membranes which in turn impact larger biological processes. Mammalian lipid absorption, synthesis and composition for maintaining systemic homeostasis are controlled mainly in the intestine, liver and adipose tissues [2]. As exemplified by the hepatitis $C$ virus (HCV), enveloped RNA viruses can alter lipid homeostasis to enhance virus replication and increase infectivity [3]. Early presentation of gastrointestinal symptoms recently seen in COVID-19 patients was common in SARS-2003 patients; these often include diarrhea, nausea, vomiting and abdominal pain [4-8]. Further, 
viable virus was detectable in patient stool samples and in sewage, which can contribute to community spread [6,9-12]. As noted by the increase in serum alanine aminotransferase, aspartate transaminase and glycemic index, SARS-CoV patients develop mild to severe liver or pancreatic dysfunction as the disease progresses [13-15]. The extent of liver and intestinal damage was noted upon examination of biopsies from fatal SARS-2003 cases [16]. Liver and enteric tissue showed fatty degeneration, cloudy swelling, apoptosis and dot necrosis of hepatocytes, as well as regional hemorrhage and vascular congestion with lymphocytic infiltration in gastrointestinal wall tissue and in hepatic and pancreatic ducts. Transient or permanent pancreatic dysfunction seen in SARS-CoV infection [15] is the result of $\beta$-cell damage and likely stems from $\beta$-cell inflammokine activation of autoreactive $T$ cells and macrophages and, if extensive, can lead to fulminant and permanent diabetes [17]. These disparate SARS-CoV digestive organ pathologies all stem from the fact that intestinal, hepatic and pancreatic cells express one or more of the coronavirus receptors, namely angiotensin-converting enzyme-2 (ACE2), dipeptidyl peptidase-4 (CD26) and CD209L [18-20]. The commonality of intestine, liver and pancreatic $\beta$-cell involvement noted in SARS-2003 and COVID-19 points to the digestive tract as a significant site of disease with the potential to alter lipid metabolism.

\section{Potential Impact of Elevated Systemic and Cellular Fatty Acid Levels in Obese Individuals Infected with SARS-CoV-2}

The number of COVID-19 patients requiring hospitalization is three-fold greater for individuals who are morbidly obese $(\mathrm{BMI}>40)$ [21]. When present as a comorbidity with type 2 diabetes mellitus (T2DM), obesity increases patient risk of death ten-fold [14].

Numerous metabolic disturbances resulting from obesity contribute to a chronic state of low-grade inflammation and a diminished host response to viral infection [22,23]. Elevated serum triacylglycerol (TAG), free fatty acids (FFA), and proinflammatory adipokines leptin and resistin, along with TNF- $\alpha$, IL-6, IL-1 $\beta$, IL-18 and MCP- 1 concurrent with lower amounts of the anti-inflammatory adipokine, adiponectin, collectively weaken the innate and adaptive immune system [24]. Following infection of an obese individual, type I interferon levels are reduced, and the natural killer cell response is attenuated. This dampened response initiates a cycle of decreased IL-12, IL-18, IFN $\gamma$ and IL-2 responses, together with lowering of the adaptive immune response [22,23]. Long-term obesity also promotes chronic inflammation and a loss of gut mucosal integrity $[25,26]$. One can speculate that compromised immune function coupled with weakened gut integrity, precipitated by obesity, provides SARS-CoV a greater opportunity to establish primary enteric infection and better ease of access to circulatory spread.

At the cellular level, accumulation of excess fatty acid stemming from obesity causes chronic endoplasmic reticulum (ER) stress response and continual activation of the unfolded protein response (UPR) pathway $[27,28]$. Under normal conditions, the ER provides the cellular machinery needed for proper protein folding, maturation, and directed trafficking of glycosylated and secretory proteins. The ER is also needed for calcium homeostasis and metabolism of complex lipids. An imbalance in these ER demands activates the evolutionarily conserved UPR pathway in an attempt to stem protein production, enhance removal of misfolded protein and control the synthesis of cellular lipid [29]. When the ER protein-folding capacity is exceeded and dysfunctional proteins accumulate, activation of the UPR pathway attempts to restore ER homeostasis by temporarily reducing global protein synthesis, enlarging ER volumes through endomembrane restructuring, increasing ER-folding capacity through the up-regulation of chaperones and foldases, and increasing protein turnover capacity through the up-regulation of ER-associated degradation (ERAD) components and ER-specific autophagy [30,31]. If ER homeostasis is unattainable, UPR initiates cell-death programs to eliminate the defective cell for the benefit of the organism [32]. The 'restore or die' decision by the cell is controlled and directed by the inositol-requiring enzyme 1 (IRE1), the activating transcription factor 6 (ATF6) and the protein kinase RNA (PKR)-like ER kinase or PERK. At times of severe ER stress and failure to restore ER homeostasis, the UPR network is forced to engage in additional SOS mechanisms, including 
ER-associated degradation (ERAD), autophagy or even cell death by apoptosis. In obese individuals, where ER stress is chronic and UPR pathways are already heightened, the added stress on the ER caused by SARS-CoV-2 replication could easily shift UPR signaling beyond homeostasis restoration towards apoptosis and greater tissue destruction [33].

\section{The Essential Role of Lipids during SARS-CoV-2 Replication and Virion Assembly}

SARS-CoV-2 replication relies on newly synthesized phospholipids or reengineered host membrane vesicles to serve as the replicative organelle that coordinates pairing of viral genomes and protein synthesis with virus assembly to complete the virus replication cycle [34-37]. Coronavirus replicative organelles are comprised of $200 \mathrm{~nm}$-wide doublemembrane vesicles (DMV) derived from the ER-Golgi vesicular transport system [38,39]. It is hypothesized that DMV structures more efficiently concentrate newly synthesized viral RNA genomes with associated virion structural proteins to better enable virus assembly and packaging. DMV could also serve to shield viral genome RNAs from recognition and destruction by innate cellular defense systems [40,41]. In concert with host cell ER factors and an increase in fatty acid synthesis [37], the SARS-CoV-2 nonstructural proteins (nsp)3, 4,6 construct the replication organelle structures $[42,43]$. Nsp3 was shown to initiate the formation of large multilamellar vesicles which are then refined with the aid of nsp4 into extensive DMV pairings and maze-like bodies. Nsp6 contributes to replication organelle formation by potentially promoting cellular autophagy and membrane lipid recycling [44]. Once completed, replication organelles act as scaffolds for the coronavirus membrane protein that in turn coordinates virus RNA-nucleocapsid assembly and subsequent lipid envelopment of virion spike and envelope proteins. Assembled coronavirus particles bud into the ER-Golgi vasculature for spike and envelope glycosylation and subsequent virion egress through the cell's secretory pathway and outside the cell [45].

Beyond providing a safe place for SARS-CoV-2 assembly, ER stress and activation of the UPR pathway incurred during virus-induced organelle remodeling can be gainfully exploited by the virus. ER UPR activation stimulates global lipid synthesis. UPR activation of IRE1 signaling results in proper RNA splicing and translation of X-box binding protein 1 (XBP1) mRNA which in turn stimulates sterol regulatory-element binding protein-1 (SREBP-1) and transcription of anabolic lipid genes including fatty acid synthase (FASN), acetyl-CoA carboxylase (ACC) and stearoyl-CoA desaturase 1 (SCD1) [46]. Thus UPR activation caused by SARS-CoV can provide much needed lipid stocks during virus and replicative organelle assembly [46]. As an added virus benefit, increased lipid stocks allow for expanded DMV luminal volumes resulting in a decreased effective concentration of misfolded virus proteins and preventing the possibility of UPR-induced apoptosis [29].

\section{The Essential Role of Lipid Addition to SARS-CoV Proteins}

SARS-CoV requires addition of lipid chains to conserved cysteine residues located adjacent to the transmembrane sections of the virus spike and envelope proteins (Figure 1) [47-49]. Lipid addition occurs through the process of cysteine palmitoylation [50]. Cysteine palmitoylation reversibly adds palmitate (C16:0), or the less common stearate (C18:0) or arachidonate (C20:0) moieties to cysteine residues that dynamically increase a protein's affinity for cellular membranes and hydrophobic pockets on neighboring proteins or protein domains. Beyond serving as a membrane tether, protein palmitoylation promotes protein shuttling between different membrane compartments [51]. Palmitoylated proteins are often categorized by their site of lipid addition and include ones with palmitoylated cysteines lying close to ( $\leq 20$ amino acid distance) or within a given protein's transmembrane spanning sequence, located at the carboxyl-terminus or near the amino-terminus, and expressing the MGC motif [52]. 
Spike protein

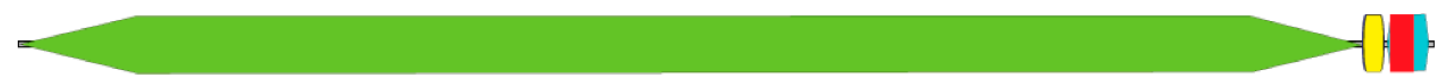

COV19: PWYIWLGFIAGLIAIVMVTIMLCCMTSCCSCLKGCCSCGSCCKFDEDDSEPVLKGVKLHYT

SARS 1: PWYVWLGFIAGLIAIVMVTILLCCMTSCCSCLKGACSCGSCCKFDEDDSEPVLKGVKLHYT

HKU1A: PWYVWLLISFSEI IFLVLLFFICCCTGCGSACFSKCHNCCDEYGGHHDFVIKTSHDD

HKU1B: PWYIWLLIVILFI IFLMILFFICCCTGCGSACFSKCHNCCDEYGGHNDFVIKASHDD

HKU1C: PWYIWLLIVILFIIFLMILFFICCCTGCGSACFSKCHNCCDEYGGHNDFVIKASHDD

NL63: PWWVWLIISVVFVVLLSLLVFCCLSTGCCGCCNCLTSSMRGCCDCGSTKLPYYEFEKVHVQ

229E: PWWVWLCISVVLIFVVSMLLLCCCSTGCCGFFSCFASS IRGCCESTKLPYYDVEKIHIQ

4480: PWYVWLLIGFAGVAMLVLLFFICCCTGCGTSCFKKCGGCCDDYTGHQELVIKTSHD

MHV: $\quad$ PWYVWLLIGLAGVAVCVLLFFICCCTGCGSCCFKKCGNCCDEYGGHQDSIVIHNIS

Envelope protein

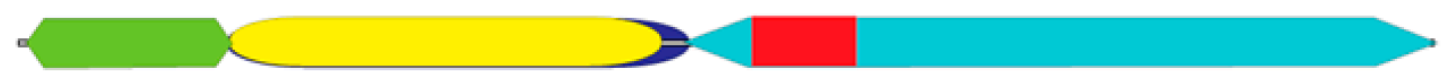

COV19: MYSFVSEETGTLIVNSVLLFLAFVVELLVTLAILTALRLCAYCCNIVNVSLVKPSFY

SARS: MYSFVSEETGTLIVNSVLLFLAFVVELLVTLAILTALRLCAYCCNIVNVSLVKPTVY

HKU1A: MVDLFFNDTAWYIGQILVLVLFCLISLIFVVAFLATIKLCMQLCGFCNFFIISPSAY

HKU1B: MVDVFFTDTAWYVGQIFFLVLSCVIFLIFVVALLATIKLCIQICGFCNIFI ISPSAY

HKU1C: MVDVFFTDTAWYVGQIFFLVLSCVIFLIFVVALLATIKLCIQICGECNIFI ISPSAY

NL63: -MFLRLIDDNGIVLNS I LWLLVMIFEFVLAMTE IKLIQLCFTCHYFFSRTLYQPVYK

229E: -MFLKLVDDHALVVNVLLWCVVLIVILLVCITI IKLIKLCFTCHMFCNRTVYGPIKN

4408: MFMADAYFADTVWYVGQI IFIVAICLLVI IVVVAFLATEKLCIQLCGMCNTLVLSPSIY

MHV: MFNLFLTDTVWYVGQIIFIFAVCLMVTIIVVAFLASIKLCIOLCGLCNTLVLSPSIY

Membrane protein

Glyco

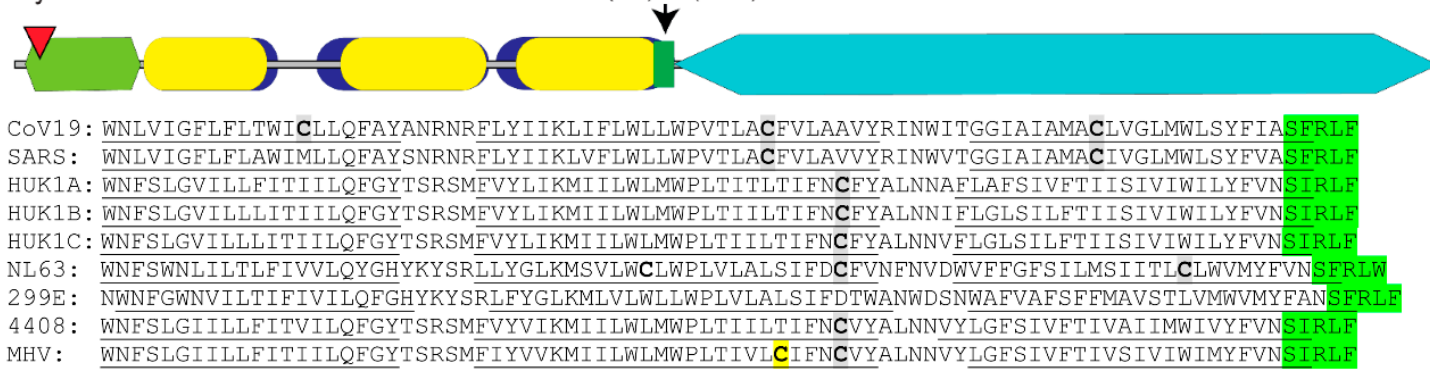

Figure 1. Distribution of palmitoylated cysteine residues in coronavirus structural proteins. Diagram of SARS-CoV-2 spike, envelope and membrane proteins depicting the relative amino acid length of their ectodomain (olive green), hydrophobic domain (blue) with internal transmembrane sequences (mustard), endodomain (teal), $N$-glycosylation (maroon triangle), conserved $\mathrm{S}(\mathrm{I} / \mathrm{F}) \mathrm{RL}(\mathrm{F} / \mathrm{W})$ motif (bright green) and cysteine clusters of proven palmitoylation (red). Actual sequences of cysteine clusters (grey highlight) with individual cysteine residues (bold) found in or near predicted transmembrane domains (underlined) for human and mouse coronavirus spike, envelope and membrane proteins are shown. In silico predicted individual cysteines (yellow) and biochemically confirmed (purple) palmitoylation sites are shown. Coronavirus spike, envelope and membrane protein amino acid sequences were derived from GenBank accession IDs for SARS-CoV-2, NC_045512; SARS-CoV-1, AY291315; human coronavirus HUK1 genotype A, AY597011; HUK1 genotype B, AY884001; HUK1 genotype C, DQ415898; human coronavirus NL63, NC_005831; 299E, AF304460; human enteric coronavirus strain 4408, FJ938067; and related murine hepatitis virus strain A59 MHV, MF618252. Coronavirus protein alignments with hydrophobic transmembrane locations were performed using Clustal Omega and TMHMM v. 2.0 programs, respectively. Identification of potential palmitoylation targets was performed using CSS-lm 4.0 and Palm-GPS algorithms set for high stringency.

Palmitoylation of viral envelope proteins usually occurs on cysteine residues located within or near their transmembrane domain [50]. Cysteine palmitoylation is catalyzed by the DHHC (Asp-His-His-Cys) rich domain palmitoyl acyltransferases that reside in the ER and Golgi [53]. These integral membrane proteins transfer palmitate residing in the DHHC motif to an unreduced cysteine target residue in the acceptor protein. Of the three coronavirus virion membrane proteins, namely spike, envelope and membrane, only the spike and envelope proteins were shown to be palmitoylated and important in virus replication [54,55]. Spike and envelope palmitoylation was shown to increase protein trafficking to replication organelles and aid in assembly of the virus envelope. Detailed 
examination of the SARS-CoV-2 spike protein endodomain reveals that it can be divided into a cysteine-rich cluster located near the viral envelope and a carboxy terminal region containing both basic and acidic residues (Figure 1). Palmitoylation of specific cysteine residues in the spike protein cysteine cluster for the related SARS-CoV-1 and mouse hepatitis virus (MHV) was found to be essential for efficient virus assembly and during initial infection when the spike protein-host cell membrane fusion event occurred (Figure 1, purple) $[49,55]$. It has been hypothesized that spike protein palmitoylation adds additional anchoring properties to the spike protein fusion domain allowing for optimum host cell fusion and virus entry by lessening torsional strain in the spike protein transmembrane domain [55].

Coronavirus envelope protein is also palmitoylated (Figure 1) [54,56]. Although abundantly expressed in the ER of infected cells, only a small portion of the envelope is incorporated into the virion structure [57]. Close association of the coronavirus envelope protein with cell membranes and other viral envelope proteins induces ER membrane curvature and allows nucleocapsid envelopment during virus budding into ER-Golgi vasculature [58]. A second property of the envelope protein is the formation of a homopentamer calcium ion channel expected to relieve ER stress by maintenance of calcium homeostasis, thus preventing UPR-induced apoptosis $[59,60]$. When occurring in close proximity to the envelope protein transmembrane sequence, palmitoylation may serve to strengthen tethering of envelope protein to the DMV.

Published evidence is lacking with respect to cysteine palmitoylation of other SARSCoV-2 proteins intimately involved with lipid membranes, namely the virion membrane protein and nsp3, 4 and 6. We postulate that if cysteine palmitoylation of these proteins were essential to their function, including tethering to the viral lipid envelope or to the $\mathrm{DMV}$, the cysteine residue would be conserved among other $\beta$-coronaviruses and be located close to or within their transmembrane sequence(s). In silico alignments of human coronaviruses, including SARS-CoV, with the prototypic MHV membrane protein or nsp3, 4 and 6 using Clustal Omega and TMHMM v. 2.0 programs to detect cysteines located in or near hydrophobic transmembrane spanning regions, along with identification of palmitoylation potential using CSS-Im 4.0 and Palm-GPS algorithms [61-64], were performed. Our data indicate that, while coronavirus membrane protein and nsp amino acid sequences vary markedly among human coronaviruses and MHV, their relative positions and number of hydrophobic transmembrane sequences are maintained (Figures 1 and 2).

The coronavirus membrane protein is a type III transmembrane glycoprotein and the most abundant glycoprotein in the virus particle [65]. The membrane protein was shown to coordinate the initial genome packaging within the nucleocapsid and its subsequent integration into the virion membrane with the envelope and spike proteins [66]. Coronavirus membrane protein can fold into either an elongated or compact conformation for which the long form is thought to be important in lipid membrane curvature and virus budding, whereas the compact version likely forms under acidic conditions and during coronavirus entry into the endosome of a new host cell [67]. In silico examination of cysteine residues in SARS-CoV-2 membrane protein predicts palmitoylation only for a similarly positioned cysteine residue in MHV (Figure 1). In silico analysis also uncovered a conserved $\mathrm{S}(\mathrm{I} / \mathrm{F}) \mathrm{RL}(\mathrm{F} / \mathrm{W})$ motif located within the junction of the third transmembrane sequence and the membrane protein endodomain (Figure 1). Based on homology with the immunoglobulin heavy chain junction region, the $S(I / F) R L(F / W)$ motif may provide conformational flexibility to coronavirus membrane proteins. 
Nsp3

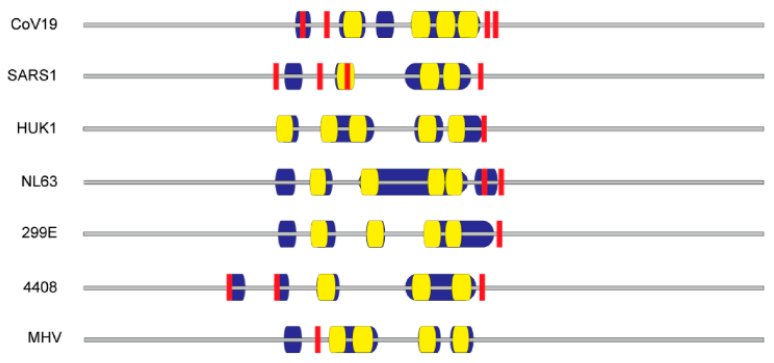

Nsp4

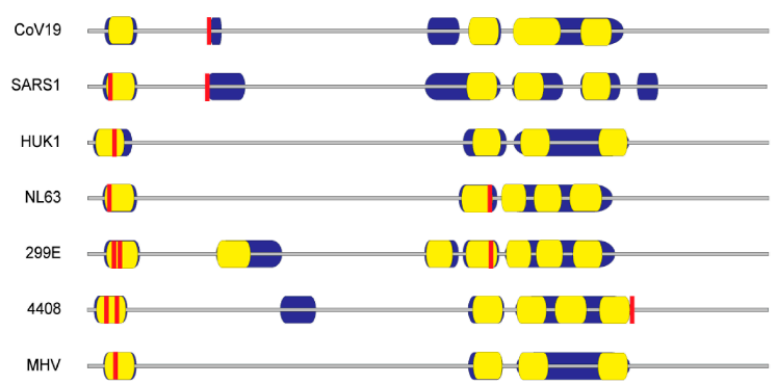

Nsp6

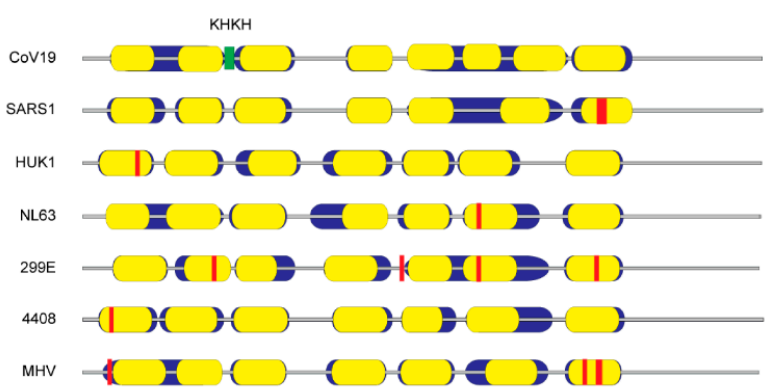

Figure 2. Distribution of potential membrane-associated palmitoylated cysteine residues in coronavirus nonstructural proteins 3,4 and 6. Diagrams show relative amino acid length with predicted hydrophobic domains (blue), internal transmembrane sequences (yellow), and consensus sites of cysteine palmitoylation (red). Coronavirus nonstructural protein sequences were obtained from GenBank accession IDs listed in Figure 1.

In silico examination of nsp3 revealed a conserved cysteine motif C(A)XCXK and palmitoylation target located at the rightward end of its hydrophobic domains for the human coronaviruses examined (Figure 2). Potential nsp4 palmitoylation occurred in the first hydrophobic domain for all the coronavirus families examined except for the SARS-CoV-2 virus (Figure 2). Surprisingly, cysteines detected in the first transmembrane domain of SARS-CoV-1 or other human coronaviruses were replaced with aromatic residues. A BLAST search of GenBank coronavirus taxid (8-27-2020) showed that unlike the reported pangolin intermediary virus isolate MP789 [68], only bat coronavirus isolate RaTG13 was devoid of cysteines and possessed 100\% cDNA sequence identity with that of SARS-CoV-2 [69]. Nsp6 contained a conserved -KHKH- junction sequence demarcating the boundaries of the 2nd and 3rd hydrophobic transmembrane domain for all coronaviruses examined, but whose utility during infection has yet to be determined (Figure 2). Although palmitoylation is predicted in seven hydrophobic regions of nsp6, we found no conserved palmitoylation site (Figure 2). While biochemical verification of these predicted palmitoylation sites is warranted, the conserved palmitoylation sites are all located in or near hydrophobic domains, thereby strengthening the argument that SARS-CoV nsp3 and nsp4 membrane 
interactions require palmitoylation for simple tethering or for more extensive ER reshaping into multilamellar vesicles and DMV pairing.

\section{Fatty Acid Synthase (FASN) and AMP-Activated Protein Kinase (AMPK): Potential Antiviral Targets to Block SARS-CoV-2 Replication and Virus Assembly}

When considering the use of lipid-modifying drugs as potential SARS-CoV-2 antivirals, we defined an antiviral as one that targets specific viral proteins or interferes with a critical step in the virus life-cycle. While sterol-altering drugs such as statins are proven to mitigate inflammation and are currently investigated to lessen the cytokine storm in COVID-19 patients (1 March 2020, clinicaltrials.gov), their use as COVID-19 antivirals remains controversial $[70,71]$. Evidence suggests that statins may reduce inflammation and interfere with SARS-CoV-2 interaction with the ACE2 receptor. However, statins may also interact with currently used COVID-19 treatments including the glucocorticoid, dexamethasone, or with protease inhibitor antivirals and reduce their potency [72]. Further, it is unclear whether statins may exacerbate COVID-19 pneumonia [73]. We elected not to pursue statins as antivirals seeing that they do not block virus replication for other enveloped RNA viruses, namely hepatitis C virus and influenza virus [74-77], and we do not expect statins to impact viral protein palmitoylation or the level of fatty acids required during assembly of replication organelles [37].

SARS-CoV-2 along with closely related Middle East respiratory syndrome $\beta$-coronavirus (MERS-CoV) increase PI3K/AKT/mTOR/S6K signaling activity, which is expected to increase production of lipid anabolic enzymes including FASN and acetyl-CoA carboxylase (ACC1) (Figure 3) [78,79]. FASN is the key cellular enzyme involved in palmitate synthesis [80]. FASN uses acetyl-CoA and malonyl-CoA as substrates to form palmitate, which in turn is used for the palmitoylation of proteins or further processed into more complex lipids for the construction of viral envelopes and replication organelles. FASN inhibitors act primarily through allosteric inhibition of FASN $\beta$-ketoacyl reductase activity, resulting in altered lipid membrane synthesis and protein palmitoylation [81]. Acetyl-CoA carboxylase is also a key metabolic enzyme in fatty acid biosynthesis. ACC1 converts mitochondriaderived acetyl-CoA to malonyl-CoA, which in turn serves the dual purpose of directing metabolic intermediates towards fatty acid synthesis or producing malonyl-CoA, and the allosteric inhibitor of carnitine palmitoyl transferase 1 [82]. This latter enzyme acts as the rate-limiting step in fatty acid degradation [82]. Control of fatty acid biosynthesis by inhibiting ACC1 or FASN enzymatic activity is expected to attenuate virus production.

Beyond direct inhibition of FASN and ACC1 enzyme activities, cellular FASN and ACC1 levels are controlled at transcription by the sterol regulatory element-binding protein (SREBP)-1 (Figure 3) [83]. The SREBP-1-dependent lipogenic pathway is normally stimulated by food ingestion, but excessively activated in the setting of obesity-linked insulin resistance [84].

Under conditions of low energy demand and sufficient fatty acid stores, SREBP-1 resides in the ER in an inactive form as a stable complex with the SREBP-cleavage activating protein (SCAP) and the insulin-induced gene protein (INSIG) [85]. INSIG bound to SREBP-1 maintains SREBP-1 in the ER and prevents SREBP-1 transport and proteolytic processing/maturation in the Golgi. During times of insufficient cellular fatty acids, INSIG is ubiquitylated and degraded, allowing SREBP-1-SCAP transport to the Golgi complex, whereby SREBP-1 is proteolytically processed by site- 1 and site- 2 proteases (S1P, S2P). Upon proteolytic maturation, SREBP-1 is translocated to the nucleus for transcriptional activation of FASN and ACC genes [86]. In cases of T2DM or obesity, where chronic elevation of insulin leads to continued increases in lipid synthesis, mechanistic findings indicate that cellular INSIG levels were reduced [87]. With heightened levels of insulin there is also increased PI3K production of phosphatidylinositol (3,4,5)-triphosphate (PIP3), activation of Akt (AKR mouse thymoma) kinase and increased nuclear SREBP-1 levels via Akt activation of the mammalian target of rapamycin (mTORC1) signaling complex (Figure 3) [88]. mTORC1 is comprised of the mTOR kinase, the adapter protein regulatoryassociated protein of mTORC1 (Raptor), the mammalian lethal SEC13 protein 8 (MLST8, 
also called G $\beta L$ ), as well as its inhibitory subunits, proline-rich Akt substrate-1 (PRAS1) and Akt target domain-interacting protein (DEP) TOR. One of the most important sensors involved in the regulation of mTORC1 activity is the tuberous sclerosis complex (TSC) heterodimer (TSC1 and TSC2). TSC acts as a GTPase for the Ras-related GTPase, Rheb (Ras homolog enriched in brain). As a Rheb-specific GTPase, TSC negatively regulates mTORC1 signaling by converting Rheb into its inactive GDP-bound state. Insulin stimulation and Akt direct phosphorylation inactivates TSC GTPase to promote GTP-Rheb activation and increase mTORC1 signaling activity. Akt also increases mTORC1 activity by phosphorylating PRAS40 (proline rich Akt substrate $40 \mathrm{kD}$ ), normally a negative regulator of mTORC1. mTORC1 promotes phosphorylation of lipin-1, a phosphatidic acid phosphatase and S6kinase activity. The normally dephosphorylated lipin-1 resides in the nucleus and limits "free form" SREBP-1 nuclear levels. Lipin-1 acts by sequestering nuclear SREBP-1 away from its lipid gene responsive elements [89]. Upon lipin-1 phosphorylation, freed SREBP-1 can now target the lipid gene responsive elements. Activated S6-kinase phosphorylates the ER SREBP-1 complex to enhance SREBP-1 Golgi transport and proteolytic maturation [90]. In cases of T2DM or obesity, where chronic insulin elevation leads to increased lipid synthesis and a lipid-rich environment, one would expect the SARS-CoV to more readily form replication organelles and increase virus production.

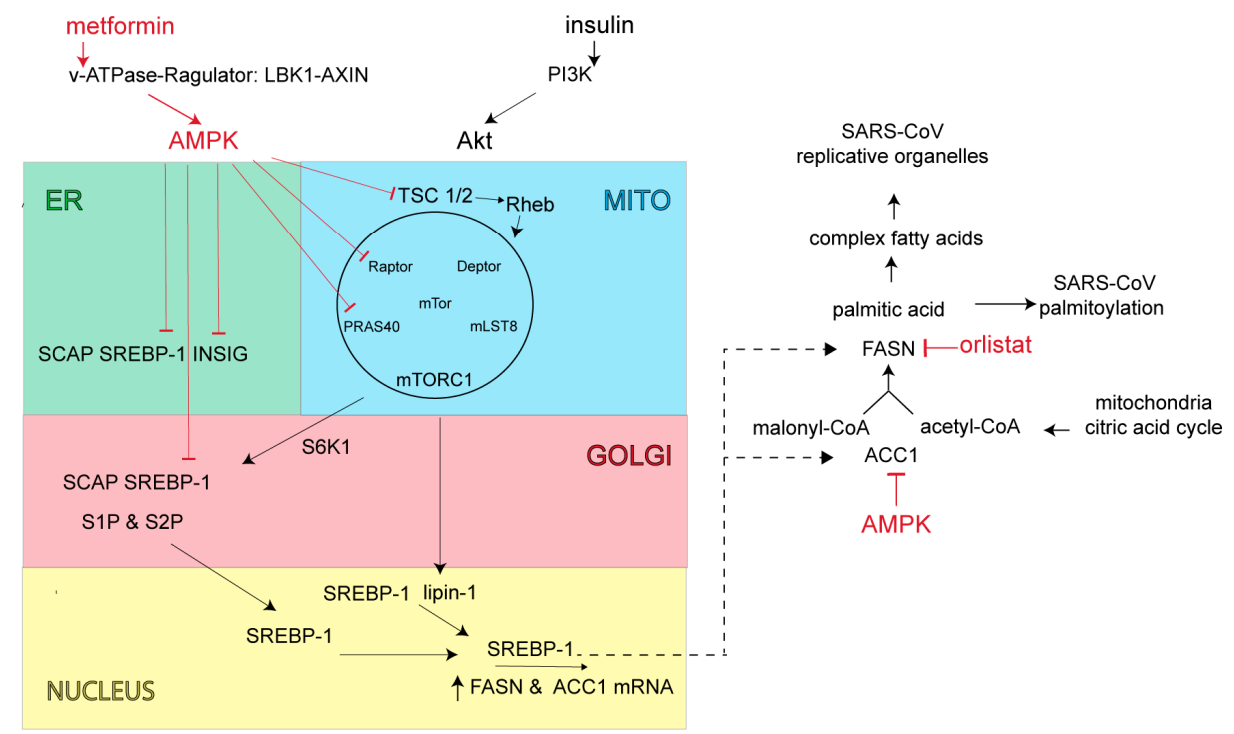

Figure 3. Overview of the lipid synthetic pathway. Insulin activation of mitochondrial (MITO) mTORC1 leads to the phosphorylation of S6K1 and lipin-1. Activated S6K1 acts on ER-resident SREBP-1 resulting in SREBP-1 transport to the Golgi, proteolytic maturation by S1P and S2P, with eventual nuclear entry and transcriptional activation of fatty-acid anabolic genes FASN and ACC1. mTORC1 activation of lipin-1 results in release of perinuclear-bound SREBP-1 for further transcriptional activation of fatty-acid anabolic genes. AMPK blocks fatty acid synthesis by acting directly on the ACC1 enzyme, or indirectly by lowering cellular FASN and ACC1 enzymes through deactivation of mTORC1 or by preventing ER SREBP-1 transport/maturation to/at the Golgi and ultimately preventing lipid gene transcription.

To counteract the insulin-induced increase in lipid synthesis and to maintain the cell's proper ATP to fat storage ratio [91], cellular AMPK turns down lipid synthesis directly through phosphorylation of the rate-limiting enzyme ACC1 and indirectly through interruption of mTORC1 signaling and subsequent SREBP-1 processing (Figure 3). AMPK inhibits mTORC1 signaling by phosphorylating TSC2 and converting Rheb into an inactive GDP-bound state, thus switching off Akt stimulation of mTORC1. AMPK also phosphorylates Raptor which leads to 14-3-3 protein binding and mTORC1 inhibition [92]. AMPK also directly blocks the SREBP-1 signaling pathway by phosphorylating both SREBP-1 and INSIG. INSIG phosphorylation blocks INSIG ubiquitination and degradation resulting in SREBP-1 retention in the ER [93]. AMPK phosphorylation of SREBP-1 prevents SREBP-1 
proteolytic processing/maturation and ultimately lipid gene transcription [94]. As SREBP-1 controls its own transcription, any increase in INSIG stability or prevention of SREBP-1 maturation would also act as a negative feedback control to further reduce overall SREBP-1 levels and ultimately cause a reduction in lipid enzymes and lipid synthesis [95].

A reduction in lipid biosynthesis through AMPK's actions is expected to attenuate coronavirus replication organelle formation as well as viral protein palmitoylation and virus production (Figure 3). As an added benefit, AMPK's action on mTORC1 will reduce cellular NFKB activity along with both cellular and systemic inflammatory responses and T-cell activation [96], which should diminish or mitigate aberrant inflammatory responses often seen in severe SARS-CoV-2 infection [97].

\section{Potential Use of Orlistat and Metformin in Controlling SARS-CoV-2 Protein Palmitoylation and Organelle Assembly}

There are a number of experimental compounds in (pre)clinical testing that inhibit FASN [81] or activate AMPK [98], and could serve as potential anti-SARS-CoV antivirals. However, only FASN inhibitor, orlistat, or AMPK activator, metformin, sold under the brand names Xenical and Glucophage, respectively, are approved for widespread clinical use and have well-established safety profiles. Orlistat is prescribed for treatment of obesity and obesity-related T2DM [99-102]. Orlistat is a saturated derivative of endogenous lipstatin isolated from Streptomyces toxytricini, which covalently binds to the active site of the thioesterase domain of FASN and directly inhibits FASN enzymatic activity (Figure 3) [103,104]. The recommended orlistat dose is one $120 \mathrm{mg}$ capsule taken orally $3 \times$ daily during fat-free meals [105]. While the primary site of orlistat accumulation is within the gut, most of the medication (95-97\%) is unabsorbed and excreted in feces; however, early clinical studies have detected low but measurable levels of orlistat in the serum when doses were prescribed above the recommended $120 \mathrm{mg}$ [106]. Metformin is a biguanide derivative widely used to treat T2DM [107]. Metformin was shown to be clinically superior in reducing glucose levels with little induction of hypoglycemia or weight gain and to reverse hepatic steatosis, improve insulin sensitivity, and improve atherosclerosis and cardiovascular dysfunction [107]. Metformin's mechanism of action was once thought to be mitochondrial, involving complex I of the electron transport chain for increased AMP and activation of AMPK [107]. However, more recent findings show that metformin activates the AMPK cascade via the formation of v-ATPase/Ragulator complex in association with liver kinase B1 (LKB1) and axis inhibition protein 1 (AXIN1). Once formed, this larger complex leads to AMPK activation and the switching off of mTORC1 (Figure 3) [108]. While metformin's actions on AMPK and mTORC1 also lead to changes in glucose and protein metabolism, mitochondrial biogenesis and mitochondrial autophagy that may impact SARS-CoV-2 replication, we focused on metformin's action on lipid metabolism. Metformin's action through AMPK reduces lipid storage, increases fatty acid oxidation, inhibits glycolysis and blocks lipogenesis. We expect metformin, acting through AMPK, to turn down palmitate synthesis and virus protein palmitoylation directly through phosphorylation of the rate-limiting enzyme ACC1. We also expect AMPK to reduce overall fatty acid synthesis and replication organelle assembly by interrupting mTORC1 signaling and subsequent SREBP-1 processing (Figure 3). In addition, orlistat's direct inhibition of FASN enzymatic activity should impair palmitate production and ultimately, viral protein palmitoylation (Figure 3).

\subsection{Insights from Other Lipid-Dependent Viruses for Use of Orlistat and Metformin in COVID-19 Treatment}

In other viral settings, orlistat and metformin were shown to inhibit replication of several flaviviruses [109-112], as well as hepatitis B virus and HCV [113-117], coxsackievirus B3 and varicella-zoster virus [118,119]. For these viruses, orlistat was shown to inhibit lipid-vesicle restructuring, viral genome replication, virion protein palmitoylation [109-111,118] and virus entry [113,114]. Metformin was shown to decrease lipid (palmitate) synthesis [119], viral RNA transcription and protein synthesis [115,116], as well 
as virus-dependent glycolysis, while increasing IFN production and blocking inflammatory cytokines [112,117]. From these observed antiviral mechanisms, orlistat and metformin are expected to decrease FASN and activate AMPK, respectively, for a predicted inhibition of viral replication organelle formation, and to block spike, membrane and envelope palmitoylation and subsequent virus assembly. Orlistat and metformin may also enhance innate cellular immunity by promoting IFN expression and suppressing deleterious IL-6 and TNF $\alpha$ (Figure 4).

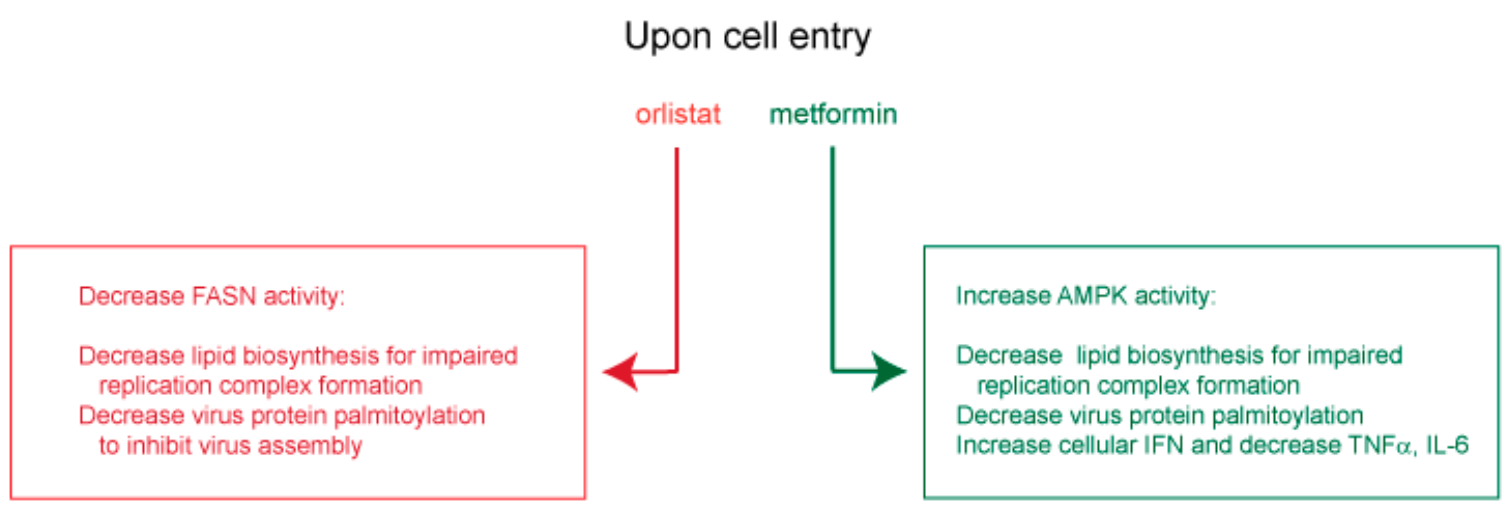

Figure 4. Predicted mechanisms of action used by orlistat and metformin to inhibit SARS-CoV-2 replication.

\subsection{Potential Clinical Utility of Orlistat and Metformin in COVID-19 Treatment}

Orlistat was shown to decrease IL-6 and TNF $\alpha$ in diabetic patients [120], and to reduce systemic inflammation and pancreatitis-induced death in obese (ob/ob) mice as measured by a lower mortality incidence and decreased serum levels of TNF $\alpha, \mathrm{MCP}-1$ and IL-6 in an acute pancreatitis mouse model [121]. Orlistat was shown to reduce intestinal microsporidiosis caused by Enterocytozoon species, as seen by a decrease in fecal spores and spore infectivity [122]. Like the lipid dependency of RNA viruses, orlistat-treated mice exhibited a direct inhibition of microsporidia viability through inhibition of sporedependent phospholipid synthesis and prevention of parasitophorous vacuoles required during Enterocytozoon spore development.

Clinical and animal studies in a variety of disease settings lend strong support for metformin as a SARS-CoV antiviral. Metformin activation of AMPK to enhance IFN signaling, decrease proinflammatory cytokines and restore immune homeostasis could abrogate cytokine storm severity in COVID-19 disease [123,124]. While clinical testing of metformin as a systemic immunometabolic drug is ongoing [125], use of metformin has already demonstrated reduced inflammation in patients and reduced insulitis in mice. Metformin has been shown to inhibit autoreactive and proinflammatory cells and to restore immune homeostasis [126], as well as to reduce IL-6, TNF $\alpha$ and intracellular adhesion molecule-1 (ICAM-1) in women with polycystic ovary syndrome [127], and to lower asthma-related hospitalization and asthma exacerbation in diabetic patients [128]. Metformin's lowering of asthma events is postulated to act through AMPK and attenuate eosinophilic-driven inflammation $[129,130]$. Metformin was shown to reduce non-alcoholic fatty liver disease and intestinal inflammation in murine models [131,132].

Consideration of metformin use as an anti-SARS-CoV antiviral to alleviate enteric pathology stems from its ability to decrease gut microbiome dysregulation and chronic bowel inflammation in T2DM [133] and inflammatory bowel disease [134]. In addition, metformin decreases the frequency of pathogenic Th17 cells and increases the frequency of beneficial regulatory T cells $[134,135]$ through activation of AMPK and subsequent reduction in activated NFKB [132]. Metformin may reduce SARS-CoV inflammatory signals in infected cells by altering AMPK-dependent signaling and down-stream suppression of cytokine gene activation. 


\subsection{Therapeutic Application of Orlistat and Metformin}

The optimal daily dose recommended for metformin is $2000 \mathrm{mg}$. When taken orally and during meals, like orlistat, the primary site of accumulation is within the gut, with elimination in the urine and feces [107]. A review of potential drug toxicity indicates that orlistat is well-tolerated; however, COVID-19 patients may need to be monitored for rare occurrence of orlistat-induced hepatic injury $[136,137]$. In rare cases $(4.3 / 100,000)$, metformin may decrease lactate uptake by the liver, thereby increasing the risk of lactic acidosis. Its use in patients with severe renal insufficiency, acidosis, congestive heart failure, liver disease and hypoxemia should be monitored [138].

It has been suggested that metformin use during COVID-19 treatment may increase SARS-CoV infectivity by augmenting the level of cellular ACE2 (by approximately 0.8fold) $[139,140]$. This increase may outweigh the benefits of preventing SARS-CoV-induced lung inflammation and damage [141,142] or, in our view, metformin's inhibition of lipid synthesis and virus replication. In added support for metformin use to treat COVID-19, we note that SARS-CoV-1 spike protein employs the metzincin protease family member TNF$\alpha$-converting enzyme (TACE) to cleave ACE2, which then enables virus entry [143-145]. Prevention of TACE protease activity attenuates SARS-CoV infection [144]. Since metformin can inhibit other metzincin family members, namely metalloproteinase (MMP)-2 and MMP-9 [146], one might infer that metformin acts in a similar inhibitory fashion on TACE protease to prevent ACE2 cleavage and virus entry. The higher levels of cellular ACE2 seen following metformin treatment may in fact reflect uncut and dysfunctional ACE2 SARS-CoV receptors.

Potential drug interactions with currently proposed COVID-19 treatment modalities can easily be avoided with simple dietary changes, increased dosage or offsets in time of drug administration (i.e., fat-soluble vitamins, cyclosporine A, https://clinicaltrials.gov, search term "COVID-19", 1 March 2020).

\section{Conclusions and Future Directions}

Approved medicines such as orlistat and metformin that act respectively on FASN and AMPK, and which are expected to inhibit virus replication and assembly or to promote gastrointestinal integrity and decrease deleterious systemic inflammation, merit serious consideration for clinical testing as anti-COVID-19 therapies (Figure 5).

In support for our hypothesis that metformin may be useful in COVID-19 management, work by Zhu et al. (2020) indicates that individuals using drugs to control their T2DM diabetes faired markedly better in hospitalization outcomes compared to those who did not use drugs [147]. Upon further examination of the authors' data (Zhu et al., Table 2), we noted that COVID-19 patients using metformin faired best overall (27.3\%) [147]. Although the small sample size did not allow for statistical significance using Z-test for proportions, the data trend did show that metformin use improved hospitalization outcomes more than $(>)$ the anti-T2DM alpha-glucosidase inhibitors $(26.7 \%),>$ thiazolidinediones $(22.2 \%)$, > sulfonylurea $(20.1 \%)$, > meglitinides $(20.0 \%)$, > dipeptidyl peptidase- 4 inhibitors $(20.0 \%)$ and $>$ insulin $(12.1 \%)$. Subsequent studies examining metformin use in diabetic individuals hospitalized for COVID-19 infection showed an association with a lower risk of death $[148,149]$.

Clinical studies for orlistat use and COVID-19 outcomes await further investigation. However, a yet to be published review of orlistat effectiveness in lowering HCV viral load in the phase 4 clinical study (NCT00207311, clinical trials.gov) may give clearer medical guidance and a possible clinical path forward to effectively treat SARS-CoV-2 infection using orlistat. 


\section{Upon oral administration}

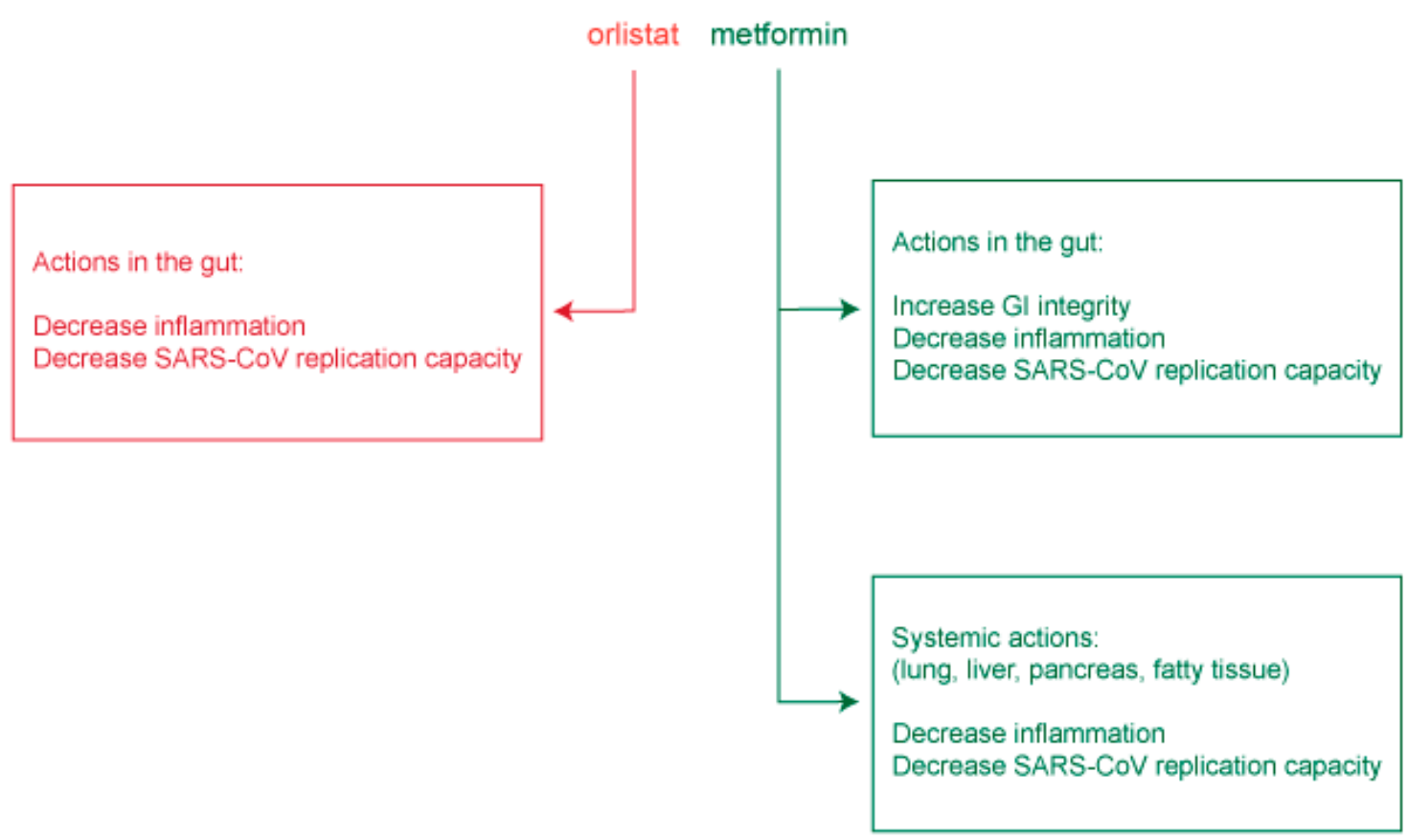

Figure 5. Predicted systemic actions by orlistat and metformin in inhibiting COVID-19 disease and pathologies.

If used in conjunction with other antivirals and anti-inflammatory drugs, orlistat and/or metformin may further suppress SARS-CoV-2 replication through overall lowering of lipid synthesis for a reduction in replication organelles and prevention of viral protein palmitoylation, thereby lowering immune-induced morbidity in high-risk and affected patients. One may envisage clinical prophylaxis using orlistat or metformin in patients following a positive test for the disease and at an early stage in their disease progression. If incorporated judiciously with other COVID-19 antivirals, both drugs may act synergistically with these antivirals to hasten patient recovery before the need for more invasive intensive care management.

Author Contributions: J.E.T. contributed to the conceptualization, formal analysis and drafting the original draft. C.A. contributed to the discussion, writing, review and editing. Both authors have read and agreed to the published version of the manuscript.

Funding: This research received no external funding.

Conflicts of Interest: The authors declare no conflict of interest.

\section{References}

1. Boroughs, L.K.; DeBerardinis, R.J. Metabolic pathways promoting cancer cell survival and growth. Nat. Cell Biol. 2015, 17, 351-359. [CrossRef] [PubMed]

2. Wang, B.; Tontonoz, P. Phospholipid remodeling in physiology and disease. Annu. Rev. Physiol. 2019, 81, 165-188. [CrossRef] [PubMed]

3. Beilstein, F.; Lemasson, M.; Pène, V.; Rainteau, D.; Demignot, S.; Rosenberg, A.R. Lysophosphatidylcholine acyltransferase 1 is downregulated by hepatitis c virus: Impact on production of lipo-viro-particles. Gut 2017, 66, 2160-2169. [CrossRef] [PubMed]

4. Zhang, J.Z. Severe acute respiratory syndrome and its lesions in digestive system. World J. Gastroenterol. 2003, 9, 1135-1138. [CrossRef] [PubMed]

5. Booth, C.M.; Matukas, L.M.; Tomlinson, G.A.; Rachlis, A.R.; Rose, D.B.; Dwosh, H.A.; Walmsley, S.L.; Mazzulli, T.; Avendano, M.; Derkach, P.; et al. Clinical features and short-term outcomes of 144 patients with sars in the greater toronto area. JAMA 2003, 289, 2801-2809. [CrossRef]

6. Holshue, M.L.; DeBolt, C.; Lindquist, S.; Lofy, K.H.; Wiesman, J.; Bruce, H.; Spitters, C.; Ericson, K.; Wilkerson, S.; Tural, A.; et al. First case of 2019 novel coronavirus in the united states. N. Engl. J. Med. 2020, 382, 929-936. [CrossRef] 
7. Song, Y.; Liu, P.; Shi, X.L.; Chu, Y.L.; Zhang, J.; Xia, J.; Gao, X.Z.; Qu, T.; Wang, M.Y. Sars-cov-2 induced diarrhoea as onset symptom in patient with covid-19. Gut 2020, 69, 1143-1144. [CrossRef]

8. Lin, L.; Jiang, X.; Zhang, Z.; Huang, S.; Zhang, Z.; Fang, Z.; Gu, Z.; Gao, L.; Shi, H.; Mai, L.; et al. Gastrointestinal symptoms of 95 cases with sars-cov-2 infection. Gut 2020, 69, 997-1001. [CrossRef]

9. Evans, M. The Epidemiology of Severe Acute Respiratory Syndrome: A Global Perspective. In Imaging in SARS; Ahuja, A., Ooi, C., Eds.; Cambridge University Press: Cambridge, UK, 2004; pp. 1-16.

10. Han, C.; Duan, C.; Zhang, S.; Spiegel, B.; Shi, H.; Wang, W.; Zhang, L.; Lin, R.; Liu, J.; Ding, Z.; et al. Digestive symptoms in covid-19 patients with mild disease severity: Clinical presentation, stool viral rna testing, and outcomes. Am. J. Gastroenterol. 2020, 115, 916-923. [CrossRef]

11. Jin, X.; Lian, J.S.; Hu, J.H.; Gao, J.; Zheng, L.; Zhang, Y.M.; Hao, S.R.; Jia, H.Y.; Cai, H.; Zhang, X.L.; et al. Epidemiological, clinical and virological characteristics of 74 cases of coronavirus-infected disease 2019 (covid-19) with gastrointestinal symptoms. Gut 2020, 69, 1002-1009. [CrossRef]

12. Wurtzer, S.; Marechal, V.; Mouchel, J.M.; Maday, Y.; Teyssou, R.; Richard, E.; Almayrac, J.L.; Moulin, L. Evaluation of lockdown effect on SARS-CoV-2 dynamics through viral genome quantification in waste water, Greater Paris, France, 5 March to 23 April 2020. Euro Surveill. 2020, 25, 38-44. [CrossRef] [PubMed]

13. Yang, X.; Yu, Y.; Xu, J.; Shu, H.; Xia, J.; Liu, H.; Wu, Y.; Zhang, L.; Yu, Z.; Fang, M.; et al. Clinical course and outcomes of critically ill patients with sars-cov-2 pneumonia in wuhan, china: A single-centered, retrospective, observational study. Lancet. Respir. Med. 2020, 8, 475-481.

14. Bornstein, S.R.; Dalan, R.; Hopkins, D.; Mingrone, G.; Boehm, B.O. Endocrine and metabolic link to coronavirus infection. Nat. Rev. Endocrinol. 2020, 16, 297-298. [CrossRef] [PubMed]

15. Yang, J.K.; Lin, S.S.; Ji, X.J.; Guo, L.M. Binding of sars coronavirus to its receptor damages islets and causes acute diabetes. Acta Diabetol. 2010, 47, 193-199. [CrossRef] [PubMed]

16. Chau, T.N.; Lee, K.C.; Yao, H.; Tsang, T.Y.; Chow, T.C.; Yeung, Y.C.; Choi, K.W.; Tso, Y.K.; Lau, T.; Lai, S.T.; et al. Sars-associated viral hepatitis caused by a novel coronavirus: Report of three cases. Hepatology 2004, 39, 302-310. [CrossRef] [PubMed]

17. Tanaka, S.; Nishida, Y.; Aida, K.; Maruyama, T.; Shimada, A.; Suzuki, M.; Shimura, H.; Takizawa, S.; Takahashi, M.; Akiyama, D.; et al. Enterovirus infection, cxc chemokine ligand 10 (cxcl10), and cxcr3 circuit: A mechanism of accelerated beta-cell failure in fulminant type 1 diabetes. Diabetes 2009, 58, 2285-2291. [CrossRef] [PubMed]

18. Tipnis, S.R.; Hooper, N.M.; Hyde, R.; Karran, E.; Christie, G.; Turner, A.J. A human homolog of angiotensin-converting enzyme. Cloning and functional expression as a captopril-insensitive carboxypeptidase. J. Biol. Chem. 2000, 275, 33238-33243. [CrossRef] [PubMed]

19. Vankadari, N.; Wilce, J.A. Emerging wuhan (covid-19) coronavirus: Glycan shield and structure prediction of spike glycoprotein and its interaction with human cd26. Emerg. Microbes Infect. 2020, 9, 601-604. [CrossRef]

20. Jeffers, S.A.; Tusell, S.M.; Gillim-Ross, L.; Hemmila, E.M.; Achenbach, J.E.; Babcock, G.J.; Thomas, W.D., Jr.; Thackray, L.B.; Young, M.D.; Mason, R.J.; et al. Cd2091 (l-sign) is a receptor for severe acute respiratory syndrome coronavirus. Proc. Natl. Acad. Sci. USA 2004, 101, 15748-15753. [CrossRef]

21. Petrilli, C.M.; Jones, S.A.; Yang, J.; Rajagopalan, H.; O’Donnell, L.F.; Chernyak, Y.; Tobin, K.; Cerfolio, R.J.; Francois, F.; Horwitz, L.I. Factors associated with hospital admission and critical illness among 5279 people with coronavirus disease 2019 in New York City: Prospective cohort study. BMJ. 2020, 369, m1966. [CrossRef]

22. Genoni, G.; Prodam, F.; Marolda, A.; Giglione, E.; Demarchi, I.; Bellone, S.; Bona, G. Obesity and infection: Two sides of one coin. Eur. J. Pediatrics 2014, 173, 25-32. [CrossRef] [PubMed]

23. Mancuso, P. Obesity and respiratory infections: Does excess adiposity weigh down host defense? Pulm. Pharmacol. Ther. 2013, 26, 412-419. [CrossRef] [PubMed]

24. Trujillo, M.E.; Scherer, P.E. Adipose tissue-derived factors: Impact on health and disease. Endocr. Rev. 2006, 27,762-778. [CrossRef] [PubMed]

25. Yiu, J.H.; Dorweiler, B.; Woo, C.W. Interaction between gut microbiota and toll-like receptor: From immunity to metabolism. J. Mol. Med. 2017, 95, 13-20. [CrossRef]

26. Cani, P.D.; Bibiloni, R.; Knauf, C.; Waget, A.; Neyrinck, A.M.; Delzenne, N.M.; Burcelin, R. Changes in gut microbiota control metabolic endotoxemia-induced inflammation in high-fat diet-induced obesity and diabetes in mice. Diabetes 2008, 57, 1470-1481. [CrossRef]

27. Cnop, M.; Ladriere, L.; Igoillo-Esteve, M.; Moura, R.F.; Cunha, D.A. Causes and cures for endoplasmic reticulum stress in lipotoxic beta-cell dysfunction. DiabetesObes. Metab. 2010, 12 (Suppl. 2), 76-82.

28. Hetz, C.; Papa, F.R. The unfolded protein response and cell fate control. Mol. Cell 2018, 69, 169-181. [CrossRef]

29. Bravo, R.; Parra, V.; Gatica, D.; Rodriguez, A.E.; Torrealba, N.; Paredes, F.; Wang, Z.V.; Zorzano, A.; Hill, J.A.; Jaimovich, E.; et al. Endoplasmic reticulum and the unfolded protein response: Dynamics and metabolic integration. Int. Rev. Cell Mol. Biol. 2013, 301, 215-290.

30. Karagöz, G.E.; Acosta-Alvear, D.; Walter, P. The unfolded protein response: Detecting and responding to fluctuations in the protein-folding capacity of the endoplasmic reticulum. Cold Spring Harb. Perspect. Biol. 2019, 1, a033886. [CrossRef]

31. Wang, B.; Tontonoz, P. Liver $x$ receptors in lipid signalling and membrane homeostasis. Nat. Rev. Endocrinol. 2018, 14, 452-463. [CrossRef] 
32. Lu, M.; Lawrence, D.A.; Marsters, S.; Acosta-Alvear, D.; Kimmig, P.; Mendez, A.S.; Paton, A.W.; Paton, J.C.; Walter, P.; Ashkenazi, A. Opposing unfolded-protein-response signals converge on death receptor 5 to control apoptosis. Science 2014, 345, 98-101. [CrossRef] [PubMed]

33. Tabas, I.; Ron, D. Integrating the mechanisms of apoptosis induced by endoplasmic reticulum stress. Nat. Cell Biol. 2011, 13, 184-190. [CrossRef] [PubMed]

34. Altan-Bonnet, N. Lipid tales of viral replication and transmission. Trends Cell Biol. 2017, 27, 201-213. [CrossRef] [PubMed]

35. Veit, M. Palmitoylation of virus proteins. Biol. Cell 2012, 104, 493-515. [CrossRef] [PubMed]

36. Stapleford, K.A.; Miller, D.J. Role of cellular lipids in positive-sense rna virus replication complex assembly and function. Viruses 2010, 2, 1055-1068. [CrossRef]

37. Yan, B.; Chu, H.; Yang, D.; Sze, K.H.; Lai, P.M.; Yuan, S.; Shuai, H.; Wang, Y.; Kao, R.Y.; Chan, J.F.; et al. Characterization of the lipidomic profile of human coronavirus-infected cells: Implications for lipid metabolism remodeling upon coronavirus replication. Viruses 2019, 11, 73. [CrossRef]

38. Neuman, B.W.; Angelini, M.M.; Buchmeier, M.J. Does form meet function in the coronavirus replicative organelle? Trends Microbiol 2014, 22, 642-647. [CrossRef]

39. Knoops, K.; Kikkert, M.; Worm, S.H.; Zevenhoven-Dobbe, J.C.; van der Meer, Y.; Koster, A.J.; Mommaas, A.M.; Snijder, E.J. Sars-coronavirus replication is supported by a reticulovesicular network of modified endoplasmic reticulum. PLoS Biol. 2008, 6, e226. [CrossRef]

40. de Wilde, A.H.; Snijder, E.J.; Kikkert, M.; van Hemert, M.J. Host factors in coronavirus replication. Curr. Top. Microbiol. Immunol. 2018, 419, 1-42.

41. Sprooten, J.; Garg, A.D. Type i interferons and endoplasmic reticulum stress in health and disease. Int. Rev. Cell Mol. Biol. 2020, 350, 63-118.

42. Angelini, M.M.; Akhlaghpour, M.; Neuman, B.W.; Buchmeier, M.J. Severe acute respiratory syndrome coronavirus nonstructural proteins 3, 4, and 6 induce double-membrane vesicles. mBio 2013, 4, e00524-13. [CrossRef] [PubMed]

43. Verheije, M.H.; Raaben, M.; Mari, M.; Te Lintelo, E.G.; Reggiori, F.; van Kuppeveld, F.J.; Rottier, P.J.; de Haan, C.A. Mouse hepatitis coronavirus rna replication depends on gbf1-mediated arf1 activation. PLoS Pathog. 2008, 4, e1000088. [CrossRef] [PubMed]

44. Cottam, E.M.; Maier, H.J.; Manifava, M.; Vaux, L.C.; Chandra-Schoenfelder, P.; Gerner, W.; Britton, P.; Ktistakis, N.T.; Wileman, T. Coronavirus nsp6 proteins generate autophagosomes from the endoplasmic reticulum via an omegasome intermediate. Autophagy 2011, 7, 1335-1347. [CrossRef] [PubMed]

45. Lim, Y.X.; Ng, Y.L.; Tam, J.P.; Liu, D.X. Human coronaviruses: A review of virus-host interactions. Diseases 2016, 4, 26. [CrossRef] [PubMed]

46. Li, S.; Kong, L.; Yu, X. The expanding roles of endoplasmic reticulum stress in virus replication and pathogenesis. Crit. Rev. Microbiol. 2015, 41, 150-164. [CrossRef]

47. McBride, C.E.; Machamer, C.E. Palmitoylation of sars-cov s protein is necessary for partitioning into detergent-resistant membranes and cell-cell fusion but not interaction with m protein. Virology 2010, 405, 139-148. [CrossRef]

48. Boscarino, J.A.; Logan, H.L.; Lacny, J.J.; Gallagher, T.M. Envelope protein palmitoylations are crucial for murine coronavirus assembly. J. Virol. 2008, 82, 2989-2999. [CrossRef]

49. Thorp, E.B.; Boscarino, J.A.; Logan, H.L.; Goletz, J.T.; Gallagher, T.M. Palmitoylations on murine coronavirus spike proteins are essential for virion assembly and infectivity. J. Virol. 2006, 80, 1280-1289. [CrossRef]

50. Resh, M.D. Fatty acylation of proteins: The long and the short of it. Prog. Lipid Res. 2016, 63, 120-131. [CrossRef]

51. Chamberlain, L.H.; Shipston, M.J. The physiology of protein s-acylation. Physiol. Rev. 2015, 95, 341-376. [CrossRef]

52. Hansen, S.G.; Grosenbach, D.W.; Hruby, D.E. Analysis of the site occupancy constraints of primary amino acid sequences in the motif directing palmitylation of the vaccinia virus 37-kda envelope protein. Virology 1999, 254, 124-137. [CrossRef] [PubMed]

53. Rana, M.S.; Lee, C.J.; Banerjee, A. The molecular mechanism of dhhc protein acyltransferases. Biochem. Soc. Trans. 2019, 47, 157-167. [CrossRef]

54. Lopez, L.A.; Riffle, A.J.; Pike, S.L.; Gardner, D.; Hogue, B.G. Importance of conserved cysteine residues in the coronavirus envelope protein. J. Virol. 2008, 82, 3000-3010. [CrossRef] [PubMed]

55. Petit, C.M.; Chouljenko, V.N.; Iyer, A.; Colgrove, R.; Farzan, M.; Knipe, D.M.; Kousoulas, K.G. Palmitoylation of the cysteine-rich endodomain of the sars-coronavirus spike glycoprotein is important for spike-mediated cell fusion. Virology 2007, 360, 264-274. [CrossRef] [PubMed]

56. Liao, Y.; Yuan, Q.; Torres, J.; Tam, J.P.; Liu, D.X. Biochemical and functional characterization of the membrane association and membrane permeabilizing activity of the severe acute respiratory syndrome coronavirus envelope protein. Virology 2006, 349, 264-275. [CrossRef] [PubMed]

57. Venkatagopalan, P.; Daskalova, S.M.; Lopez, L.A.; Dolezal, K.A.; Hogue, B.G. Coronavirus envelope (e) protein remains at the site of assembly. Virology 2015, 478, 75-85. [CrossRef]

58. Schoeman, D.; Fielding, B.C. Coronavirus envelope protein: Current knowledge. Virol. J. 2019, 16, 69. [CrossRef]

59. Nieva, J.L.; Madan, V.; Carrasco, L. Viroporins: Structure and biological functions. Nat. Rev. Microbiol. 2012, 10, 563-574. [CrossRef]

60. Ruch, T.R.; Machamer, C.E. The coronavirus e protein: Assembly and beyond. Viruses 2012, 4, 363-382. [CrossRef]

61. Ning, W.; Jiang, P.; Guo, Y.; Wang, C.; Tan, X.; Zhang, W.; Peng, D.; Xue, Y. Gps-palm: A deep learning-based graphic presentation system for the prediction of s-palmitoylation sites in proteins. Brief. Bioinform. 2020. [CrossRef] 
62. Krogh, A.; Larsson, B.; von Heijne, G.; Sonnhammer, E.L. Predicting transmembrane protein topology with a hidden markov model: Application to complete genomes. J. Mol. Biol. 2001, 305, 567-580. [CrossRef] [PubMed]

63. Ren, J.; Wen, L.; Gao, X.; Jin, C.; Xue, Y.; Yao, X. Css-palm 2.0: An updated software for palmitoylation sites prediction. Protein Eng. Des. Sel. Peds 2008, 21, 639-644. [CrossRef]

64. Sievers, F.; Wilm, A.; Dineen, D.; Gibson, T.J.; Karplus, K.; Li, W.; Lopez, R.; McWilliam, H.; Remmert, M.; Söding, J.; et al. Fast, scalable generation of high-quality protein multiple sequence alignments using clustal omega. Mol. Syst. Biol. 2011, 7, 539. [CrossRef]

65. Rottier, P.J.M. The coronavirus membrane glycoprotein. In The Coronaviridae; Siddell, S.G., Ed.; Springer: Boston, MA, USA, 1995; pp. 115-139.

66. Kuo, L.; Hurst-Hess, K.R.; Koetzner, C.A.; Masters, P.S. Analyses of coronavirus assembly interactions with interspecies membrane and nucleocapsid protein chimeras. J. Virol. 2016, 90, 4357-4368. [CrossRef]

67. Neuman, B.W.; Buchmeier, M.J. Supramolecular architecture of the coronavirus particle. Adv. Virus Res. 2016, 96, 1-27.

68. Liu, P.; Jiang, J.Z.; Wan, X.F.; Hua, Y.; Li, L.; Zhou, J.; Wang, X.; Hou, F.; Chen, J.; Zou, J.; et al. Are pangolins the intermediate host of the 2019 novel coronavirus (sars-cov-2)? PLoS Pathog. 2020, 16, e1008421. [CrossRef] [PubMed]

69. Zhou, P.; Yang, X.L.; Wang, X.G.; Hu, B.; Zhang, L.; Zhang, W.; Si, H.R.; Zhu, Y.; Li, B.; Huang, C.L.; et al. A pneumonia outbreak associated with a new coronavirus of probable bat origin. Nature 2020, 579, 270-273. [CrossRef] [PubMed]

70. Subir, R.; Jagat, J.M.; Kalyan, K.G. Pros and cons for use of statins in people with coronavirus disease-19 (covid-19). Diabetes Metab. Syndr. 2020, 14, 1225-1229. [CrossRef] [PubMed]

71. Zhao, T.; Peng, L. Letter in response to the article: Pros and cons for use of statins in 59 people with coronavirus disease-19 (covid-19)(ray, s et al.). Diabetes Metab. Syndr. 2020, 15, 21. [CrossRef] [PubMed]

72. Ward, N.C.; Watts, G.F.; Eckel, R.H. Statin toxicity. Circ. Res. 2019, 124, 328-350. [CrossRef]

73. Mascitelli, L.; Grant, W.B.; Goldstein, M.R. Cholesterol levels, statins, vitamin d, and associated risk of pneumonia. Eur. J. Clin. Pharmacol. 2012, 68, 889-890. [CrossRef] [PubMed]

74. Milazzo, L.; Meroni, L.; Galazzi, M.; Cesari, M.; Caramma, I.; Marchetti, G.; Galli, M.; Antinori, S. Does fluvastatin favour hcv replication in vivo? A pilot study on hiv-hcv coinfected patients. J. Viral Hepat. 2009, 16, 479-484. [CrossRef] [PubMed]

75. Verpaalen, B.; Neyts, J.; Delang, L. Are statins a viable option for the treatment of infections with the hepatitis c virus? Antivir. Res. 2014, 105, 92-99. [CrossRef]

76. Blanchet, M.; Le, Q.T.; Seidah, N.G.; Labonté, P. Statins can exert dual, concentration dependent effects on hcv entry in vitro. Antivir. Res. 2016, 128, 43-48. [CrossRef] [PubMed]

77. Davidson, S. Treating influenza infection, from now and into the future. Front Immunol 2018, 9, 1946. [CrossRef]

78. Kindrachuk, J.; Ork, B.; Hart, B.J.; Mazur, S.; Holbrook, M.R.; Frieman, M.B.; Traynor, D.; Johnson, R.F.; Dyall, J.; Kuhn, J.H.; et al. Antiviral potential of erk/mapk and pi3k/akt/mtor signaling modulation for middle east respiratory syndrome coronavirus infection as identified by temporal kinome analysis. Antimicrob. Agents Chemother. 2015, 59, 1088-1099. [CrossRef]

79. Appelberg, S.; Gupta, S.; Svensson Akusjärvi, S.; Ambikan, A.T.; Mikaeloff, F.; Saccon, E.; Végvári, Á.; Benfeitas, R.; Sperk, M.; Ståhlberg, M.; et al. Dysregulation in akt/mtor/hif-1 signaling identified by proteo-transcriptomics of sars-cov- 2 infected cells. Emerg. Microbes Infect. 2020, 9, 1748-1760. [CrossRef]

80. Jones, S.F.; Infante, J.R. Molecular pathways: Fatty acid synthase. Clin. Cancer Res. Off. J. Am. Assoc. Cancer Res. 2015, 21, 5434-5438. [CrossRef]

81. Jiang, H.; Gan, T.; Zhang, J.; Ma, Q.; Liang, Y.; Zhao, Y. The structures and bioactivities of fatty acid synthase inhibitors. Curr. Med. Chem. 2019, 26, 7081-7101. [CrossRef]

82. Hardie, D.G.; Ross, F.A.; Hawley, S.A. Ampk: A nutrient and energy sensor that maintains energy homeostasis. Nat. Rev. Mol. Cell Biol. 2012, 13, 251-262. [CrossRef]

83. Eberle, D.; Hegarty, B.; Bossard, P.; Ferre, P.; Foufelle, F. Srebp transcription factors: Master regulators of lipid homeostasis. Biochimie 2004, 86, 839-848. [CrossRef] [PubMed]

84. Shimomura, I.; Bashmakov, Y.; Horton, J.D. Increased levels of nuclear srebp-1c associated with fatty livers in two mouse models of diabetes mellitus. J. Biol. Chem. 1999, 274, 30028-30032. [CrossRef] [PubMed]

85. Yabe, D.; Xia, Z.P.; Adams, C.M.; Rawson, R.B. Three mutations in sterol-sensing domain of scap block interaction with insig and render srebp cleavage insensitive to sterols. Proc. Natl. Acad. Sci. USA 2002, 99, 16672-16677. [CrossRef] [PubMed]

86. Gong, Y.; Lee, J.N.; Lee, P.C.; Goldstein, J.L.; Brown, M.S.; Ye, J. Sterol-regulated ubiquitination and degradation of insig-1 creates a convergent mechanism for feedback control of cholesterol synthesis and uptake. Cell Metab. 2006, 3, 15-24. [CrossRef] [PubMed]

87. Yellaturu, C.R.; Deng, X.; Park, E.A.; Raghow, R.; Elam, M.B. Insulin enhances the biogenesis of nuclear sterol regulatory elementbinding protein (srebp)-1c by posttranscriptional down-regulation of insig-2a and its dissociation from srebp cleavage-activating protein (scap).Srebp-1c complex. J. Biol. Chem. 2009, 284, 31726-31734. [CrossRef]

88. Laplante, M.; Sabatini, D.M. An emerging role of mtor in lipid biosynthesis. Curr. Biol. 2009, 19, R1046-R1052. [CrossRef]

89. Peterson, T.R.; Sengupta, S.S.; Harris, T.E.; Carmack, A.E.; Kang, S.A.; Balderas, E.; Guertin, D.A.; Madden, K.L.; Carpenter, A.E.; Finck, B.N.; et al. Mtor complex 1 regulates lipin 1 localization to control the srebp pathway. Cell 2011, 146, 408-420. [CrossRef]

90. Dong, Q.; Majumdar, G.; O'Meally, R.N.; Cole, R.N.; Elam, M.B.; Raghow, R. Insulin-induced de novo lipid synthesis occurs mainly via mtor-dependent regulation of proteostasis of srebp-1c. Mol. Cell. Biochem. 2020, 463, 13-31. [CrossRef] 
91. Kahn, B.B.; Alquier, T.; Carling, D.; Hardie, D.G. Amp-activated protein kinase: Ancient energy gauge provides clues to modern understanding of metabolism. Cell Metab. 2005, 1, 15-25. [CrossRef]

92. Dunlop, E.A.; Tee, A.R. The kinase triad, ampk, mtorc1 and ulk1, maintains energy and nutrient homoeostasis. Biochem. Soc. Trans. 2013, 41, 939-943. [CrossRef]

93. Han, Y.; Hu, Z.; Cui, A.; Liu, Z.; Ma, F.; Xue, Y.; Liu, Y.; Zhang, F.; Zhao, Z.; Yu, Y.; et al. Post-translational regulation of lipogenesis via ampk-dependent phosphorylation of insulin-induced gene. Nat. Commun. 2019, 10, 623. [CrossRef] [PubMed]

94. Li, Y.; Xu, S.; Mihaylova, M.M.; Zheng, B.; Hou, X.; Jiang, B.; Park, O.; Luo, Z.; Lefai, E.; Shyy, J.Y.; et al. Ampk phosphorylates and inhibits srebp activity to attenuate hepatic steatosis and atherosclerosis in diet-induced insulin-resistant mice. Cell Metab. 2011, 13, 376-388. [CrossRef] [PubMed]

95. Dorotea, D.; Koya, D.; Ha, H. Recent insights into srebp as a direct mediator of kidney fibrosis via lipid-independent pathways. Front. Pharmacol. 2020, 11, 265. [CrossRef] [PubMed]

96. O'Neill, L.A.; Hardie, D.G. Metabolism of inflammation limited by ampk and pseudo-starvation. Nature 2013, 493, 346-355. [CrossRef] [PubMed]

97. Ma, E.H.; Poffenberger, M.C.; Wong, A.H.; Jones, R.G. The role of ampk in t cell metabolism and function. Curr. Opin. Immunol. 2017, 46, 45-52. [CrossRef]

98. Cameron, K.O.; Kurumbail, R.G. Recent progress in the identification of adenosine monophosphate-activated protein kinase (ampk) activators. Bioorganic Med. Chem. Lett. 2016, 26, 5139-5148. [CrossRef]

99. Jensen, M.D.; Ryan, D.H.; Apovian, C.M.; Ard, J.D.; Comuzzie, A.G.; Donato, K.A.; Hu, F.B.; Hubbard, V.S.; Jakicic, J.M.; Kushner, R.F.; et al. 2013 aha/acc/tos guideline for the management of overweight and obesity in adults: A report of the american college of cardiology/american heart association task force on practice guidelines and the obesity society. J. Am. Coll. Cardiol. 2014, 63, 2985-3023. [CrossRef]

100. Charakida, M.; Tousoulis, D.; Finer, N. Drug treatment of obesity in the cardiovascular patient. Curr. Opin. Cardiol. 2013, 28, 584-591. [CrossRef]

101. Siebenhofer, A.; Jeitler, K.; Horvath, K.; Berghold, A.; Siering, U.; Semlitsch, T. Long-term effects of weight-reducing drugs in hypertensive patients. Cochrane Database Syst. Rev. 2013, Cd007654. [CrossRef]

102. Yanovski, S.Z.; Yanovski, J.A. Long-term drug treatment for obesity: A systematic and clinical review. JAMA 2014, 311, 74-86. [CrossRef]

103. Browne, C.D.; Hindmarsh, E.J.; Smith, J.W. Inhibition of endothelial cell proliferation and angiogenesis by orlistat, a fatty acid synthase inhibitor. Faseb J. Off. Publ. Fed. Am. Soc. Exp. Biol. 2006, 20, 2027-2035. [CrossRef] [PubMed]

104. Pemble, C.W.t.; Johnson, L.C.; Kridel, S.J.; Lowther, W.T. Crystal structure of the thioesterase domain of human fatty acid synthase inhibited by orlistat. Nat. Struct. Mol. Biol. 2007, 14, 704-709. [CrossRef] [PubMed]

105. Guerciolini, R. Mode of action of orlistat. Int. J. Obes. Relat. Metab. Disord. J. Int. Assoc. Study Obes. 1997, 21 (Suppl. 3), S12-S23.

106. Zhi, J.; Mulligan, T.E.; Hauptman, J.B. Long-term systemic exposure of orlistat, a lipase inhibitor, and its metabolites in obese patients. J. Clin. Pharmacol. 1999, 39, 41-46. [CrossRef]

107. Foretz, M.; Guigas, B.; Bertrand, L.; Pollak, M.; Viollet, B. Metformin: From mechanisms of action to therapies. Cell Metab. 2014, 20, 953-966. [CrossRef]

108. Zhang, C.S.; Li, M.; Ma, T.; Zong, Y.; Cui, J.; Feng, J.W.; Wu, Y.Q.; Lin, S.Y.; Lin, S.C. Metformin activates ampk through the lysosomal pathway. Cell Metab. 2016, 24, 521-522. [CrossRef]

109. Hitakarun, A.; Khongwichit, S.; Wikan, N.; Roytrakul, S.; Yoksan, S.; Rajakam, S.; Davidson, A.D.; Smith, D.R. Evaluation of the antiviral activity of orlistat (tetrahydrolipstatin) against dengue virus, japanese encephalitis virus, zika virus and chikungunya virus. Sci. Rep. 2020, 10, 1499. [CrossRef]

110. Bakhache, W.; Neyret, A.; McKellar, J.; Clop, C.; Bernard, E.; Weger-Lucarelli, J.; Briant, L. Fatty acid synthase and stearoyl-coa desaturase-1 are conserved druggable cofactors of old world alphavirus genome replication. Antivir. Res. 2019, 172, 104642. [CrossRef]

111. Tongluan, N.; Ramphan, S.; Wintachai, P.; Jaresitthikunchai, J.; Khongwichit, S.; Wikan, N.; Rajakam, S.; Yoksan, S.; Wongsiriroj, N.; Roytrakul, S.; et al. Involvement of fatty acid synthase in dengue virus infection. Virol. J. 2017, 14, 28. [CrossRef]

112. Singh, S.; Singh, P.K.; Suhail, H.; Arumugaswami, V.; Pellett, P.E.; Giri, S.; Kumar, A. Amp-activated protein kinase restricts zika virus replication in endothelial cells by potentiating innate antiviral responses and inhibiting glycolysis. J. Immunol. 2020, 204, 1810-1824. [CrossRef]

113. Esser, K.; Lucifora, J.; Wettengel, J.; Singethan, K.; Glinzer, A.; Zernecke, A.; Protzer, U. Lipase inhibitor orlistat prevents hepatitis $\mathrm{b}$ virus infection by targeting an early step in the virus life cycle. Antivir. Res. 2018, 151, 4-7. [CrossRef] [PubMed]

114. Yang, W.; Hood, B.L.; Chadwick, S.L.; Liu, S.; Watkins, S.C.; Luo, G.; Conrads, T.P.; Wang, T. Fatty acid synthase is upregulated during hepatitis c virus infection and regulates hepatitis c virus entry and production. Hepatology 2008, 48, 1396-1403. [CrossRef] [PubMed]

115. Xun, Y.H.; Zhang, Y.J.; Pan, Q.C.; Mao, R.C.; Qin, Y.L.; Liu, H.Y.; Zhang, Y.M.; Yu, Y.S.; Tang, Z.H.; Lu, M.J.; et al. Metformin inhibits hepatitis b virus protein production and replication in human hepatoma cells. J. Viral Hepat. 2014, 21, 597-603. [CrossRef] [PubMed] 
116. Del Campo, J.A.; Garcia-Valdecasas, M.; Gil-Gomez, A.; Rojas, A.; Gallego, P.; Ampuero, J.; Gallego-Duran, R.; Pastor, H.; Grande, L.; Padillo, F.J.; et al. Simvastatin and metformin inhibit cell growth in hepatitis c virus infected cells via mtor increasing pten and autophagy. PLoS ONE 2018, 13, e0191805. [CrossRef] [PubMed]

117. Tsai, W.L.; Chang, T.H.; Sun, W.C.; Chan, H.H.; Wu, C.C.; Hsu, P.I.; Cheng, J.S.; Yu, M.L. Metformin activates type i interferon signaling against hcv via activation of adenosine monophosphate-activated protein kinase. Oncotarget 2017, 8, 91928-91937. [CrossRef]

118. Ammer, E.; Nietzsche, S.; Rien, C.; Kuhnl, A.; Mader, T.; Heller, R.; Sauerbrei, A.; Henke, A. The anti-obesity drug orlistat reveals anti-viral activity. Med Microbiol. Immunol. 2015, 204, 635-645. [CrossRef]

119. Xie, W.; Wang, L.; Dai, Q.; Yu, H.; He, X.; Xiong, J.; Sheng, H.; Zhang, D.; Xin, R.; Qi, Y.; et al. Activation of ampk restricts coxsackievirus b3 replication by inhibiting lipid accumulation. J Mol Cell Cardiol 2015, 85, 155-167. [CrossRef]

120. Samuelsson, L.; Gottsater, A.; Lindgarde, F. Decreasing levels of tumour necrosis factor alpha and interleukin 6 during lowering of body mass index with orlistat or placebo in obese subjects with cardiovascular risk factors. DiabetesObes. Metab. 2003, 5, 195-201. [CrossRef]

121. Navina, S.; Acharya, C.; DeLany, J.P.; Orlichenko, L.S.; Baty, C.J.; Shiva, S.S.; Durgampudi, C.; Karlsson, J.M.; Lee, K.; Bae, K.T.; et al. Lipotoxicity causes multisystem organ failure and exacerbates acute pancreatitis in obesity. Sci. Transl. Med. 2011, 3, 107ra110. [CrossRef]

122. Abou-El-Naga, I.F.; Said, D.E.; Gaafar, M.R.; Ahmed, S.M.; El-Deeb, S.A. A new scope for orlistat: Effect of approved anti-obesity drug against experimental microsporidiosis. Med Mycol. 2019, 57, 181-195. [CrossRef]

123. Ursini, F.; Russo, E.; Pellino, G.; D’Angelo, S.; Chiaravalloti, A.; De Sarro, G.; Manfredini, R.; De Giorgio, R. Metformin and autoimmunity: A "new deal" of an old drug. Front Immunol 2018, 9, 1236. [CrossRef] [PubMed]

124. Chen, G.; Wu, D.; Guo, W.; Cao, Y.; Huang, D.; Wang, H.; Wang, T.; Zhang, X.; Chen, H.; Yu, H.; et al. Clinical and immunologic features in severe and moderate coronavirus disease 2019. J. Clin. Investig. 2020, 130, 2620-2629. [CrossRef] [PubMed]

125. Ouyang, J.; Isnard, S.; Lin, J.; Fombuena, B.; Marette, A.; Routy, B.; Chen, Y.; Routy, J.P. Metformin effect on gut microbiota: Insights for hiv-related inflammation. Aids Res. Ther. 2020, 17, 10. [CrossRef] [PubMed]

126. Pollak, M. The effects of metformin on gut microbiota and the immune system as research frontiers. Diabetologia 2017, 60, 1662-1667. [CrossRef] [PubMed]

127. Victor, V.M.; Rovira-Llopis, S.; Banuls, C.; Diaz-Morales, N.; Lopez-Domenech, S.; Escribano-Lopez, I.; Rios-Navarro, C.; Alvarez, A.; Gomez, M.; Rocha, M.; et al. Metformin modulates human leukocyte/endothelial cell interactions and proinflammatory cytokines in polycystic ovary syndrome patients. Atherosclerosis 2015, 242, 167-173. [CrossRef]

128. Li, C.Y.; Erickson, S.R.; Wu, C.H. Metformin use and asthma outcomes among patients with concurrent asthma and diabetes. Respirology 2016, 21, 1210-1218. [CrossRef]

129. Calixto, M.C.; Lintomen, L.; Andre, D.M.; Leiria, L.O.; Ferreira, D.; Lellis-Santos, C.; Anhe, G.F.; Bordin, S.; Landgraf, R.G.; Antunes, E. Metformin attenuates the exacerbation of the allergic eosinophilic inflammation in high fat-diet-induced obesity in mice. PLoS ONE 2013, 8, e76786. [CrossRef]

130. Park, C.S.; Bang, B.R.; Kwon, H.S.; Moon, K.A.; Kim, T.B.; Lee, K.Y.; Moon, H.B.; Cho, Y.S. Metformin reduces airway inflammation and remodeling via activation of amp-activated protein kinase. Biochem. Pharmacol. 2012, 84, 1660-1670. [CrossRef]

131. Brandt, A.; Hernandez-Arriaga, A.; Kehm, R.; Sanchez, V.; Jin, C.J.; Nier, A.; Baumann, A.; Camarinha-Silva, A.; Bergheim, I. Metformin attenuates the onset of non-alcoholic fatty liver disease and affects intestinal microbiota and barrier in small intestine. Sci. Rep. 2019, 9, 6668. [CrossRef]

132. Koh, S.J.; Kim, J.M.; Kim, I.K.; Ko, S.H.; Kim, J.S. Anti-inflammatory mechanism of metformin and its effects in intestinal inflammation and colitis-associated colon cancer. J. Gastroenterol. Hepatol. 2014, 29, 502-510. [CrossRef]

133. Gurung, M.; Li, Z.; You, H.; Rodrigues, R.; Jump, D.B.; Morgun, A.; Shulzhenko, N. Role of gut microbiota in type 2 diabetes pathophysiology. EBioMedicine 2020, 51, 102590. [CrossRef] [PubMed]

134. Lee, S.Y.; Lee, S.H.; Yang, E.J.; Kim, E.K.; Kim, J.K.; Shin, D.Y.; Cho, M.L. Metformin ameliorates inflammatory bowel disease by suppression of the stat 3 signaling pathway and regulation of the between th17/treg balance. PLoS ONE 2015, 10, e0135858. [CrossRef] [PubMed]

135. Duan, W.; Ding, Y.; Yu, X.; Ma, D.; Yang, B.; Li, Y.; Huang, L.; Chen, Z.; Zheng, J.; Yang, C. Metformin mitigates autoimmune insulitis by inhibiting th1 and th17 responses while promoting treg production. Am. J. Transl. Res. 2019, 11, 2393-2402. [PubMed]

136. Filippatos, T.D.; Derdemezis, C.S.; Gazi, I.F.; Nakou, E.S.; Mikhailidis, D.P.; Elisaf, M.S. Orlistat-associated adverse effects and drug interactions: A critical review. Drug Saf. 2008, 31, 53-65. [CrossRef] [PubMed]

137. Morris, M.; Lane, P.; Lee, K.; Parks, D. An integrated analysis of liver safety data from orlistat clinical trials. Obes. Facts 2012, 5, 485-494. [CrossRef]

138. Powers, A.C. Diabetes mellitus: Diagnosis, classification, and pathophysiology. In Harrison's Principles of Internal Medicine, 19th ed.; Kasper, D.L., Hauser, S.L., Jameson, J.L., Fauci, A.S., Longo, D.L., Loscalzo, J., Eds.; McGraw Hill: New York, NY, USA, 2015; Volume 2, p. 417e.

139. Zhang, J.; Dong, J.; Martin, M.; He, M.; Gongol, B.; Marin, T.L.; Chen, L.; Shi, X.; Yin, Y.; Shang, F.; et al. Amp-activated protein kinase phosphorylation of angiotensin-converting enzyme 2 in endothelium mitigates pulmonary hypertension. Am. J. Respir. Crit. Care Med. 2018, 198, 509-520. [CrossRef] 
140. Ursini, F.; Ciaffi, J.; Paola Landini, M.; Meliconi, R. Covid-19 and diabetes: Is metformin a friend or foe? Diabetes Res. Clin. Pract. 2020, 164, 108167. [CrossRef]

141. Sodhi, C.P.; Wohlford-Lenane, C.; Yamaguchi, Y.; Prindle, T.; Fulton, W.B.; Wang, S.; McCray, P.B., Jr.; Chappell, M.; Hackam, D.J.; Jia, H. Attenuation of pulmonary ace2 activity impairs inactivation of des-arg9 bradykinin/bkb1r axis and facilitates lps-induced neutrophil infiltration. Am. J. Physiol. Lung Cell. Mol. Physiol. 2018, 314, L17-L31. [CrossRef]

142. Kuba, K.; Imai, Y.; Rao, S.; Gao, H.; Guo, F.; Guan, B.; Huan, Y.; Yang, P.; Zhang, Y.; Deng, W.; et al. A crucial role of angiotensin converting enzyme 2 (ace2) in sars coronavirus-induced lung injury. Nat. Med. 2005, 11, 875-879. [CrossRef]

143. Lambert, D.W.; Yarski, M.; Warner, F.J.; Thornhill, P.; Parkin, E.T.; Smith, A.I.; Hooper, N.M.; Turner, A.J. Tumor necrosis factor-alpha convertase (adam17) mediates regulated ectodomain shedding of the severe-acute respiratory syndrome-coronavirus (sars-cov) receptor, angiotensin-converting enzyme-2 (ace2). J. Biol. Chem. 2005, 280, 30113-30119. [CrossRef]

144. Haga, S.; Yamamoto, N.; Nakai-Murakami, C.; Osawa, Y.; Tokunaga, K.; Sata, T.; Yamamoto, N.; Sasazuki, T.; Ishizaka, Y. Modulation of tnf- $\alpha$-converting enzyme by the spike protein of sars-cov and ace 2 induces tnf- $\alpha$ production and facilitates viral entry. Proc. Natl. Acad. Sci. USA 2008, 105, 7809-7814. [CrossRef] [PubMed]

145. Stocker, W.; Grams, F.; Baumann, U.; Reinemer, P.; Gomis-Ruth, F.X.; McKay, D.B.; Bode, W. The metzincins-topological and sequential relations between the astacins, adamalysins, serralysins, and matrixins (collagenases) define a superfamily of zinc-peptidases. Protein Sci. A Publ. Protein Soc. 1995, 4, 823-840. [CrossRef] [PubMed]

146. Liang, F.; Wang, Y.G.; Wang, C. Metformin inhibited growth, invasion and metastasis of esophageal squamous cell carcinoma in vitro and in vivo. Cell. Physiol. Biochem. 2018, 51, 1276-1286. [CrossRef] [PubMed]

147. Zhu, L.; She, Z.G.; Cheng, X.; Qin, J.J.; Zhang, X.J.; Cai, J.; Lei, F.; Wang, H.; Xie, J.; Wang, W.; et al. Association of blood glucose control and outcomes in patients with covid-19 and pre-existing type 2 diabetes. Cell Metab. 2020, 31, 1068-1077. [CrossRef] [PubMed]

148. Lalau, J.D.; Al-Salameh, A.; Hadjadj, S.; Goronflot, T.; Wiernsperger, N.; Pichelin, M.; Allix, I.; Amadou, C.; Bourron, O.; Duriez, T.; et al. Metformin use is associated with a reduced risk of mortality in patients with diabetes hospitalised for covid-19. Diabetes Metab. 2020, 101216. [CrossRef]

149. Luo, P.; Qiu, L.; Liu, Y.; Liu, X.L.; Zheng, J.L.; Xue, H.Y.; Liu, W.H.; Liu, D.; Li, J. Metformin treatment was associated with decreased mortality in covid-19 patients with diabetes in a retrospective analysis. Am. J. Trop. Med. Hyg. 2020, 103, 69-72. [CrossRef] 